\title{
DISTRIBUTION OF ABO AND RHESUS BLOOD GROUPS IN RELATION TO SMOKING HABIT
}

\author{
BY \\ GEOFFREY J. BOURKE \\ Department of Social Medicine, Trinity College, Dublin \\ AND \\ JOHN P. O'RIORDAN \\ National Blood Transfusion Association of Ireland
}

It has been shown that concordance of smoking habits occurs more frequently in monozygotic than in dizygotic twins (Friberg, Kaij, Dencker, and Jonsson, 1959; Todd and Mason, 1959) even when the identical twins are reared apart (Fisher, 1958). This latter finding confutes the hypothesis of reciprocal influence between the twins as an important cause of concordance and lends support to the view that the genotype is relevant to smoking habits. After these twin studies a search was begun to determine if any characteristics inherited by man might be associated with smoking, and investigation of blood groups in relation to smoking habit appeared an obvious starting point.

Analysis of the blood groups of smokers and nonsmokers in male twin data was undertaken by Todd and Mason (1959) with negative results; the sample, however, was very small and would have disclosed only a major difference in the blood group frequencies of smokers and non-smokers. Cohen and Thomas (1962) studied the smoking habits of white male blood donors in Baltimore and noted a relationship between the $\mathrm{ABO}$ blood groups and smoking habit. They found a significant excess of Group B persons among the non-smokers and occasional smokers as compared with other cigarette smokers (that is, light, moderate, and heavy) or with heavy cigarette smokers in particular.

It was felt that the Baltimore study merited further research before one could regard the association between smoking and blood groups as having been firmly established; accordingly a survey was undertaken in the Republic of Ireland to ascertain if the work of the American authors could be confirmed.

\section{Study Population and Method}

The study population comprised 10,386 healthy blood donors (8,038 males, 2,348 females) accepted by the National Blood Transfusion Association from December 3, 1962, to February 21, 1963, inclusive. A pre-coded questionnaire was completed by an interviewer who obtained from each donor the information set out below.

\begin{tabular}{|c|c|c|}
\hline 1 & $\begin{array}{l}\text { Whether he/she now smokes } \\
\text { cigarettes? } \ldots \quad \ldots\end{array}$ & $\begin{array}{l}\text { Yes } \\
\text { No }\end{array}$ \\
\hline 2 & $\begin{array}{l}\text { If No-Whether he/she ever } \\
\text { smoked cigarettes? }\end{array}$ & $\begin{array}{l}\text { Yes } \\
\text { No }\end{array}$ \\
\hline 3 & $\begin{array}{l}\text { Amount usually smoked } \\
\text { (present and past smokers) } \\
\text { per day? } \quad \text {... }\end{array}$ & $\begin{array}{l}5 \text { or less } \\
6-10 \\
11-15 \\
16-20 \\
\text { Over } 20\end{array}$ \\
\hline 4 & $\begin{array}{l}\text { Whether he/she now smokes } \\
\text { a pipe? } \quad \ldots \quad \ldots \quad \ldots\end{array}$ & $\begin{array}{l}\text { Yes } \\
\text { No }\end{array}$ \\
\hline 5 & 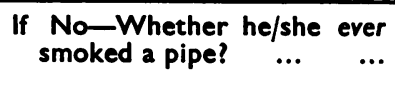 & $\begin{array}{l}\text { Yes } \\
\text { No }\end{array}$ \\
\hline 6 & $\begin{array}{l}\text { Amount usually smoked } \\
\text { (present and past smokers) } \\
\text { per week? ... } \quad \ldots \quad \ldots\end{array}$ & $\begin{array}{l}\text { Less than } 1 \text { oz. } \\
1 \text { but not } 3 \text { oz. } \\
3 \text { but not } 5 \text { oz. } \\
5 \text { oz. and Over }\end{array}$ \\
\hline
\end{tabular}


In addition the age, social group, and employment status of each donor was recorded to determine how representative the sample was in relation to these factors in the population of Ireland according to the 1951 census. The completed questionnaires were then sent to the Records Department of the National Blood Transfusion Association where the $A B O$ and $R h$ groups were inserted in the appropriate column. All the information was transferred to punch cards for analysis.

Sample in Relation to Age, Social Group, and EMPLOYMENT Status as COMPARED WITH THE Census of Population of IReland (1951)

The blood donor sample was compared with the 1951 census figures for age, social group, and employment status. It was appreciated, before the survey was undertaken, that a sample of adult blood donors would be appreciably different from the general adult population, but it was considered of interest to know precisely how biased the sample was.

AGE.-The age distribution within the sample for both sexes is quite similar with a tendency for the females to be a little younger. In the donor sample $47 \cdot 7$ per cent. are in the 20 to 29 age group and there is a deficiency of the $\mathbf{5 0}$ and over age group for both sexes $(6 \cdot 2$ per cent); the corresponding figures for the general population aged 15 years and over are 19.0 per cent. and 34.7 per cent. respectively.

Social Group.-While it is possible to compare the male sample with the 1951 census figures, in the case of the female sample it is not, since no breakdown is available in the sample figures of females allocated to social group by reason of their husband's occupation, and those assigned to social group by virtue of their own occupation.

In the donor sample only $5 \cdot 3$ per cent. of the males were engaged in agricultural occupations as compared with $44 \cdot 1$ per cent. of the general population aged 14 years and over. On the other hand, there was an excess of both professional and wageearner groups in the sample as compared with the general population aged 14 years and over.

Employment Status.-In the sample 69.7 per cent. of the males were working for an employer and 4.6 per cent. self-employed as compared with the figures of $44 \cdot 7$ and $24 \cdot 5$ per cent. respectively in the Irish population aged 14 years and over.

\section{RESULTS}

Table I shows that the distribution of the ABO groups in the present series of 10,386 persons does not differ significantly at the 5 per cent. level, from that for the Republic of Ireland (Dawson, 1963). When, however, consideration is given to the $R h$ groups, a significant difference is evident between the sample proportions and those of the Irish Republic. The $\mathrm{Rh}$ negative proportion in our series is 18.0 per cent. as compared with a national figure of 16.9 per cent. It has, however, been pointed out (Hackett, Dawson, and Dawson, 1956; Hackett and Dawson, 1958) that the proportion of Rh-negative persons is higher in the central eastern part of the country, from which the blood donor sample was drawn exclusively during the time of this study.

For the total sample there is no significant difference between any of the blood groups in the proportion falling into each of the three cigarettesmoking categories (Table II, opposite); and a separate analysis for each sex leads to a similar conclusion.

Table III (opposite) shows, for each sex, that the quantity of cigarettes smoked varies little between the ABO groups, and that there are no significant differences between the average amount smoked by the $\mathrm{Rh}$-positive and $\mathrm{Rh}$-negative groups. As might be expected, the average quantity smoked by females is appreciably less than that smoked by males. Furthermore, analysis of cigarette consumption by present- and past-smokers does not suggest any change in habits.

TABLE I

BLOOD GROUP DISTRIBUTIONS IN SAMPLE AND IN THE REPUBLIC OF IRELAND

\begin{tabular}{|c|c|c|c|c|c|c|c|c|c|c|c|}
\hline \multirow{2}{*}{\multicolumn{5}{|c|}{ Study }} & \multicolumn{5}{|c|}{ ABO Blood Group } & \multicolumn{2}{|c|}{ Rhesus Group } \\
\hline & & & & & $\mathbf{O}$ & $\mathbf{A}$ & B & $\mathbf{A B}$ & Total & Positive & Negative \\
\hline Present Series. . & $\cdots$ & $\cdots$ & $\begin{array}{l}\text { No. . . } \\
\text { Per cent. }\end{array}$ & $\cdots$ & $\begin{array}{r}5,775 \\
55 \cdot 6\end{array}$ & $\begin{array}{r}3,120 \\
30 \cdot 0\end{array}$ & $\begin{array}{r}1,194 \\
11 \cdot 5\end{array}$ & $\begin{array}{l}297 \\
2 \cdot 9\end{array}$ & $\begin{array}{r}10,386 \\
100 \cdot 0\end{array}$ & $\begin{array}{r}8,514 \\
82 \cdot 0\end{array}$ & $\begin{array}{r}1,872 \\
18 \cdot 0\end{array}$ \\
\hline Republic of Ireland Series & $\cdots$ & $\cdots$ & $\begin{array}{l}\text { No. . . } \\
\text { Per cent. }\end{array}$ & $\begin{array}{l}\cdots \\
\cdots\end{array}$ & $\begin{array}{r}65,548 \\
55 \cdot 9\end{array}$ & $\begin{array}{r}35,923 \\
30 \cdot 6\end{array}$ & $\begin{array}{r}12,771 \\
10.9\end{array}$ & $\begin{array}{r}3,045 \\
2 \cdot 6\end{array}$ & $\begin{array}{r}117,287 \\
100 \cdot 0\end{array}$ & $\begin{array}{r}97,457 \\
83 \cdot 1\end{array}$ & $\begin{array}{r}19,830 \\
16.9\end{array}$ \\
\hline
\end{tabular}


TABLE II

CIGARETTE SMOKING HABITS AND BLOOD GROUPS

\begin{tabular}{|c|c|c|c|c|c|c|c|c|c|c|c|c|c|c|c|}
\hline \multirow{3}{*}{\multicolumn{3}{|c|}{ Cigarette Smoking Habits }} & \multicolumn{9}{|c|}{ ABO Blood Group } & \multicolumn{4}{|c|}{ Rhesus Group } \\
\hline & & & \multicolumn{2}{|c|}{$\mathbf{O}$} & \multicolumn{2}{|c|}{$\mathbf{A}$} & \multicolumn{2}{|c|}{$\mathbf{B}$} & \multicolumn{2}{|c|}{$\mathbf{A B}$} & \multirow{2}{*}{ Total } & \multicolumn{2}{|c|}{ Positive } & \multicolumn{2}{|c|}{ Negative } \\
\hline & & & No. & $\begin{array}{c}\text { Per } \\
\text { cent. }\end{array}$ & No. & $\begin{array}{c}\text { Per } \\
\text { cent. }\end{array}$ & No. & $\begin{array}{c}\text { Per } \\
\text { cent. }\end{array}$ & No. & $\begin{array}{c}\text { Per } \\
\text { cent. }\end{array}$ & & No. & $\begin{array}{c}\text { Per } \\
\text { cent. }\end{array}$ & No. & $\begin{array}{c}\text { Per } \\
\text { cent. }\end{array}$ \\
\hline $\begin{array}{l}\text { Smoke now } \\
\text { Used to smoke } \\
\text { Never smoked }\end{array}$ & $\begin{array}{l}\ddot{*} \\
\cdots\end{array}$ & $\begin{array}{l}\cdots \\
\cdots\end{array}$ & $\begin{array}{r}2,949 \\
740 \\
2,086\end{array}$ & $\begin{array}{l}51 \cdot 1 \\
12 \cdot 8 \\
36 \cdot 1\end{array}$ & $\begin{array}{r}1,601 \\
404 \\
1,115\end{array}$ & $\begin{array}{l}51 \cdot 3 \\
12 \cdot 9 \\
35 \cdot 8\end{array}$ & $\begin{array}{l}608 \\
150 \\
436\end{array}$ & $\begin{array}{l}50 \cdot 9 \\
12 \cdot 6 \\
36 \cdot 5\end{array}$ & $\begin{array}{r}150 \\
45 \\
102\end{array}$ & $\begin{array}{l}50 \cdot 5 \\
15 \cdot 2 \\
34 \cdot 3\end{array}$ & $\begin{array}{l}\mathbf{5}, 308 \\
1,339 \\
\mathbf{3 , 7 3 9}\end{array}$ & $\begin{array}{l}4,344 \\
1,078 \\
3,092\end{array}$ & $\begin{array}{l}51 \cdot 0 \\
12 \cdot 7 \\
36 \cdot 3\end{array}$ & $\begin{array}{l}964 \\
261 \\
647\end{array}$ & $\begin{array}{l}51 \cdot 5 \\
13 \cdot 9 \\
34 \cdot 6\end{array}$ \\
\hline Total & . & $\ldots$ & 5,775 & $100 \cdot 0$ & 3,120 & $100 \cdot 0$ & 1,194 & $100 \cdot 0$ & 297 & $100 \cdot 0$ & 10,386 & 8,514 & $100 \cdot 0$ & 1,872 & $100 \cdot 0$ \\
\hline
\end{tabular}

TABLE III

DAILY CIGARETTE CONSUMPTION AND BLOOD GROUPS

\begin{tabular}{|c|c|c|c|c|c|c|c|c|c|c|c|c|c|c|c|}
\hline \multirow{3}{*}{\multicolumn{2}{|c|}{ Sex }} & \multirow{3}{*}{$\begin{array}{c}\text { No. of } \\
\text { Cigarettes } \\
\text { Smoked Daily }\end{array}$} & \multicolumn{9}{|c|}{ ABO Blood Group } & \multicolumn{4}{|c|}{ Rhesus Group } \\
\hline & & & \multicolumn{2}{|l|}{$\mathbf{0}$} & \multicolumn{2}{|c|}{$\mathbf{A}$} & \multicolumn{2}{|c|}{ B } & \multicolumn{2}{|c|}{$\mathbf{A B}$} & \multirow[b]{2}{*}{ Total } & \multicolumn{2}{|c|}{ Positive } & \multicolumn{2}{|c|}{ Negative } \\
\hline & & & No. & $\begin{array}{c}\text { Per } \\
\text { cent. }\end{array}$ & No. & $\begin{array}{c}\text { Per } \\
\text { cent. }\end{array}$ & No. & $\begin{array}{c}\text { Per } \\
\text { cent. }\end{array}$ & No. & $\begin{array}{c}\text { Per } \\
\text { cent. }\end{array}$ & & No. & $\begin{array}{l}\text { Per } \\
\text { cent. }\end{array}$ & No. & $\begin{array}{c}\text { Per } \\
\text { cent. }\end{array}$ \\
\hline \multirow{4}{*}{ Male } & \multirow{4}{*}{.. } & $\begin{array}{c}5 \text { or less } \\
6-10 \\
11-15 \\
16-20 \\
\text { Over } 20\end{array}$ & $\begin{array}{l}431 \\
689 \\
553 \\
485 \\
897\end{array}$ & $\begin{array}{l}14 \cdot 1 \\
22 \cdot 6 \\
18 \cdot 1 \\
15 \cdot 9 \\
29 \cdot 3\end{array}$ & $\begin{array}{l}233 \\
387 \\
301 \\
269 \\
467\end{array}$ & $\begin{array}{l}14 \cdot 0 \\
23 \cdot 4 \\
18 \cdot 2 \\
16 \cdot 2 \\
28 \cdot 2\end{array}$ & $\begin{array}{r}82 \\
142 \\
122 \\
98 \\
190\end{array}$ & $\begin{array}{l}12.9 \\
22.4 \\
19 \cdot 2 \\
15.5 \\
30.0\end{array}$ & $\begin{array}{l}27 \\
33 \\
27 \\
21 \\
52\end{array}$ & $\begin{array}{l}16 \cdot 9 \\
20.6 \\
16.9 \\
13 \cdot 1 \\
32.5\end{array}$ & $\begin{array}{r}773 \\
1,251 \\
1,003 \\
873 \\
1,606\end{array}$ & $\begin{array}{r}629 \\
1,006 \\
821 \\
727 \\
1,318\end{array}$ & $\begin{array}{l}14 \cdot 0 \\
22 \cdot 4 \\
18 \cdot 2 \\
16 \cdot 2 \\
29 \cdot 2\end{array}$ & $\begin{array}{l}144 \\
245 \\
182 \\
146 \\
288\end{array}$ & $\begin{array}{l}14 \cdot 3 \\
24 \cdot 4 \\
18 \cdot 1 \\
14 \cdot 5 \\
28 \cdot 7\end{array}$ \\
\hline & & Total & 3,055 & $100 \cdot 0$ & 1,657 & $100 \cdot 0$ & 634 & $100 \cdot 0$ & 160 & $100 \cdot 0$ & 5,506 & 4,501 & $100 \cdot 0$ & 1,005 & $100 \cdot 0$ \\
\hline & & $\overline{\mathbf{x}}$ & $14 \cdot 19$ & & $14 \cdot 06$ & & $14 \cdot 36$ & & $14 \cdot 19$ & & $14 \cdot 17$ & $14 \cdot 22$ & & 13.94 & \\
\hline & & $\frac{\sigma}{\sqrt{n}}$ & 0.130 & & 0.176 & & 0.285 & & 0.567 & & 0.097 & $0 \cdot 107$ & & $0 \cdot 227$ & \\
\hline \multirow{4}{*}{\multicolumn{2}{|c|}{ Female }} & $\begin{array}{c}5 \text { or less } \\
6-10 \\
11-15 \\
16-20 \\
\text { Over } 20\end{array}$ & $\begin{array}{r}251 \\
192 \\
89 \\
44 \\
58\end{array}$ & $\begin{array}{r}39 \cdot 6 \\
30 \cdot 3 \\
14 \cdot 0 \\
6 \cdot 9 \\
9 \cdot 2\end{array}$ & $\begin{array}{r}142 \\
102 \\
49 \\
31 \\
24\end{array}$ & $\begin{array}{r}40 \cdot 8 \\
29 \cdot 3 \\
14.1 \\
8.9 \\
6.9\end{array}$ & $\begin{array}{r}60 \\
29 \\
14 \\
8 \\
13\end{array}$ & $\begin{array}{r}48 \cdot 4 \\
23 \cdot 4 \\
11 \cdot 3 \\
6 \cdot 5 \\
10 \cdot 4\end{array}$ & $\begin{array}{r}13 \\
9 \\
5 \\
5 \\
3\end{array}$ & $\begin{array}{r}37 \cdot 1 \\
25 \cdot 7 \\
14 \cdot 3 \\
14 \cdot 3 \\
8 \cdot 6\end{array}$ & $\begin{array}{r}466 \\
332 \\
157 \\
88 \\
98\end{array}$ & $\begin{array}{r}377 \\
274 \\
126 \\
72 \\
72\end{array}$ & $\begin{array}{r}40.9 \\
29.8 \\
13.7 \\
7.8 \\
7.8\end{array}$ & $\begin{array}{l}89 \\
58 \\
31 \\
16 \\
26\end{array}$ & $\begin{array}{r}40.5 \\
26.4 \\
14.0 \\
7.3 \\
11.8\end{array}$ \\
\hline & & Total & 634 & $100 \cdot 0$ & 348 & $100 \cdot 0$ & 124 & $100 \cdot 0$ & 35 & $100 \cdot 0$ & 1,141 & 921 & $100 \cdot 0$ & 220 & $100 \cdot 0$ \\
\hline & & $\overline{\mathbf{x}}$ & $8 \cdot 79$ & & $8 \cdot 59$ & & $8 \cdot 37$ & & $9 \cdot 57$ & & $8 \cdot 71$ & $8 \cdot 59$ & & $9 \cdot 18$ & \\
\hline & & $\frac{\sigma}{\sqrt{n}}$ & 0.252 & & $0 \cdot 340$ & & 0.569 & & $1 \cdot 071$ & & $0 \cdot 187$ & 0.209 & & 0.428 & \\
\hline
\end{tabular}

Table IV (overleaf) shows no significant difference between any of the ABO and $\mathrm{Rh}$ groups in the proportion found in each of the three pipesmoking subdivisions. Furthermore, the quantity of tobacco consumed by male pipe-smokers is virtually constant from one blood group to another. As with the cigarette-smokers, there is no suggestion of any change in the amount of tobacco consumed.

Two factors which might have influenced the results in the paper were considered:

Social Groups.-The fact that considerable bias exists in the sample as compared with the social groups in the general population should not affect the validity of the results because analysis of the blood groups by social group does not show any significant differences.
Age.-While age does not affect blood group it does affect smoking habits, to the extent that the proportion of non-smokers decreases as age increases. However, it is not thought that this association exerts any influence on the results because the age distribution within each blond group is very similar; indeed, corrections for variations in the age distribution within each blood group for each sex substantiates this belief.

\section{Discussion}

In an effort to determine whether or not constitutional differences exist between smokers and nonsmokers, workers in Johns Hopkins University investigated the smoking habits of healthy male blood donors in relation to two geneticallydetermined characteristics, phenylthiourea tasting 
TABLE IV

MALES: PIPE SMOKING HABITS AND WEEKLY PIPE TOBACCO CONSUMPTION AND BLOOD GROUPS

\begin{tabular}{|c|c|c|c|c|c|c|c|c|c|c|c|c|c|c|}
\hline \multirow{3}{*}{\multicolumn{2}{|c|}{ Pipe Smoking }} & \multicolumn{9}{|c|}{ ABO Blood Group } & \multicolumn{4}{|c|}{ Rhesus Group } \\
\hline & & \multicolumn{2}{|c|}{$\mathbf{0}$} & \multicolumn{2}{|c|}{$\mathbf{A}$} & \multicolumn{2}{|c|}{$\mathbf{B}$} & \multicolumn{2}{|c|}{$\mathbf{A B}$} & \multirow[b]{2}{*}{ Total } & \multicolumn{2}{|c|}{ Positive } & \multicolumn{2}{|c|}{ Negative } \\
\hline & & No. & $\begin{array}{c}\text { Per } \\
\text { cent. }\end{array}$ & No. & $\begin{array}{c}\text { Per } \\
\text { cent. }\end{array}$ & No. & $\begin{array}{l}\text { Per } \\
\text { cent. }\end{array}$ & No. & $\begin{array}{c}\text { Per } \\
\text { cent. }\end{array}$ & & No. & $\begin{array}{c}\text { Per } \\
\text { cent. }\end{array}$ & No. & $\begin{array}{l}\text { Per } \\
\text { cent. }\end{array}$ \\
\hline \multirow[t]{3}{*}{ Habit } & $\begin{array}{l}\text { Smoke now } \\
\text { Used to smoke } \\
\text { Never smoked }\end{array}$ & $\begin{array}{r}472 \\
375 \\
3,604 \\
\end{array}$ & $\begin{array}{r}10 \cdot 6 \\
8 \cdot 4 \\
81 \cdot 0 \\
\end{array}$ & $\begin{array}{r}252 \\
200 \\
1,959 \\
\end{array}$ & $\begin{array}{r}10 \cdot 5 \\
8 \cdot 3 \\
81 \cdot 2 \\
\end{array}$ & $\begin{array}{r}94 \\
71 \\
777 \\
\end{array}$ & $\begin{array}{r}10 \cdot 0 \\
7 \cdot 5 \\
82 \cdot 5 \\
\end{array}$ & $\begin{array}{r}21 \\
21 \\
192 \\
\end{array}$ & $\begin{array}{r}9 \cdot 0 \\
9.0 \\
82 \cdot 0\end{array}$ & $\begin{array}{r}839 \\
667 \\
6,532 \\
\end{array}$ & $\begin{array}{r}671 \\
554 \\
5,372 \\
\end{array}$ & $\begin{array}{r}10 \cdot 2 \\
8 \cdot 4 \\
81 \cdot 4 \\
\end{array}$ & $\begin{array}{r}168 \\
113 \\
1,160 \\
\end{array}$ & $\begin{array}{r}11 \cdot 7 \\
7 \cdot 8 \\
80 \cdot 5\end{array}$ \\
\hline & Total & 4,451 & $100 \cdot 0$ & 2,411 & $100 \cdot 0$ & 942 & $100 \cdot 0$ & 234 & $100 \cdot 0$ & 8,038 & 6,597 & $100 \cdot 0$ & 1,441 & $100 \cdot 0$ \\
\hline & \multicolumn{7}{|c|}{$\mathrm{ABO}: \chi^{2}=1.899 ; n=6 ; 0.95>\mathrm{P}>0.90$} & \multicolumn{5}{|c|}{ Rh: $\chi^{2}=3 \cdot 074 ; n=2: 0 \cdot 30>\mathbf{P}>0 \cdot 20$} & & \\
\hline \multirow{4}{*}{$\begin{array}{c}\text { Tobacco } \\
\text { Smoked } \\
\text { Weekly } \\
\text { (oz.) } \\
\text { by Those } \\
\text { who ever } \\
\text { Smoked }\end{array}$} & $\begin{array}{l}\text { Less than } 1 \\
1 \text { but not } 3 \\
3 \text { but not } 5 \\
5 \text { and Over }\end{array}$ & $\begin{array}{r}202 \\
439 \\
169 \\
37\end{array}$ & $\begin{array}{r}23 \cdot 8 \\
51 \cdot 8 \\
20 \cdot 0 \\
4 \cdot 4\end{array}$ & $\begin{array}{r}111 \\
238 \\
84 \\
19\end{array}$ & $\begin{array}{r}24 \cdot 5 \\
52 \cdot 7 \\
18 \cdot 6 \\
4 \cdot 2\end{array}$ & $\begin{array}{r}47 \\
84 \\
25 \\
9\end{array}$ & $\begin{array}{r}28 \cdot 5 \\
50 \cdot 9 \\
15 \cdot 2 \\
5 \cdot 4\end{array}$ & $\begin{array}{r}9 \\
27 \\
5 \\
1\end{array}$ & $\begin{array}{r}21 \cdot 4 \\
64 \cdot 3 \\
11.9 \\
2.4\end{array}$ & $\begin{array}{r}369 \\
788 \\
283 \\
66\end{array}$ & $\begin{array}{r}307 \\
633 \\
233 \\
52\end{array}$ & $\begin{array}{r}25 \cdot 1 \\
51 \cdot 7 \\
19 \cdot 0 \\
4 \cdot 2\end{array}$ & $\begin{array}{r}62 \\
155 \\
50 \\
14\end{array}$ & $\begin{array}{r}22 \cdot 1 \\
55 \cdot 2 \\
17 \cdot 8 \\
4 \cdot 9\end{array}$ \\
\hline & Total & 847 & $100 \cdot 0$ & 452 & $100 \cdot 0$ & 165 & $100 \cdot 0$ & 42 & $100 \cdot 0$ & 1,506 & 1,225 & $100 \cdot 0$ & 281 & $100 \cdot 0$ \\
\hline & $\overline{\mathbf{x}}$ & $2 \cdot 22$ & & $2 \cdot 17$ & & $2 \cdot 09$ & & $2 \cdot 01$ & & $2 \cdot 18$ & $2 \cdot 17$ & & $2 \cdot 22$ & \\
\hline & $\frac{\sigma}{\sqrt{n}}$ & 0.048 & & 0.066 & & $0 \cdot 109$ & & 0.217 & & 0.036 & 0.040 & & 0.084 & \\
\hline
\end{tabular}

and blood groups. In the first study (Thomas and Cohen, 1960) they demonstrated an excess of phenylthiourea tasters among heavy cigarette smokers both whites and Negroes. In a second study (Cohen and Thomas, 1962) they examined the distribution of the $\mathrm{ABO}$ and $\mathrm{Rh}$ blood groups in relation to smoking habit, and showed, among 1,005 white male donors whose blood group frequencies were representative of the Baltimore area, a significant deficiency of Group B persons among heavy cigarette smokers, and an excess of Group B among the pooled group of non-smokers and occasional smokers; in addition, an excess of $\mathrm{Rh}$-negative subjects was found in the white occasional smoker group. A similar study of blood groups and smoking habits among 393 Negro males was entirely negative.

Apart altogether from contributing further to the knowledge that genotype exercises a considerable influence on smoking habits, this association between smoking habits and Group B would, if confirmed, be of importance in relation to lung cancer and lead to further lines of research. The distribution of ABO blood groups in patients with lung cancer is apparently normal (Aird, Bentall, Mehigan, and Roberts, 1954; McConnell, Clarke, and Downton, 1954; Walther, Raeburn, and Case, 1956) and no deficiency of Group B has been observed. It has been suggested (British Medical Journal, 1962) that, if the results of both the cigarette and the lung cancer studies are correct, Group B persons, despite the fact that they are not heavy smokers, may have a special tendency to develop carcinoma of the lung.
The findings in the present study of a sample of blood donors conflict with those of Cohen and Thomas (1962) because no significant relationship is demonstrable between smoking habit, or quantity of pipe or cigarette tobacco consumed, and a particular $\mathrm{ABO}$ or $\mathrm{Rh}$ blood group; furthermore, the $\mathrm{ABO}$ blood group distribution of the sample is not significantly different from the distribution of these groups in the Republic of Ireland.

Several criticisms of the Baltimore study have been made (British Medical Journal, 1962); the sample was small, and the appreciable probability of the findings being due to chance indicated the desirability for further study. In addition, no mention is made of ethnic group and it is possible that the sample of white donors included, for example, a racial group high in Group B who for religious or other reasons were non-smokers or occasional smokers. The cosmopolitan nature of many North American cities makes inquiry into racial origin an important factor in comparative blood group studies, since it is well known that different races have different blood group antigen frequencies. However, the authors themselves were aware that the association found in their study between blood groups and smoking could not be regarded as firm and were of the opinion that the results warranted further investigation. This, of course, would be in keeping with the maxim of Roberts (1955) referring to associations between blood groups and disease, that the association should be regarded as an indication for collecting further data unless a probability of $1: 1000$ is reached. 


\section{SUMMARY}

Inquiry into the smoking habits of 10,386 blood donors (8,038 males; 2,348 females) whose ABO blood group distribution did not differ significantly from the known distribution of blood groups in the Republic of Ireland does not reveal any association between the type of smoking habit, or the amount of pipe or cigarette tobacco consumed, and a particular ABO or Rh blood group.

We wish to thank the staff of the National Blood Transfusion Association, particularly Sister J. Begley and Commdt P. J. Kelly, and the interviewers, Mrs $\mathbf{O}$. McAulay and Mrs J. Hayes, for their able assistance. We are also indebted to Mrs E. McSweeney for clerical help.

\section{REFERENCES}

Aird, I., Bentall, H. H., Mehigen, J. A., and Roberts, J. A. Fraser (1954). Brit. med. J., 2, 315.
Brit. med.J. (1962). 1, 932.

Census of Population of Ireland (1951). Vol. II, Part 1, p. 41 (Gov. Publ.)

(1946, 1951). "General Report", p. 102, p. 118 (Gov. Publ.).

Cohen, B. H., and Thomas, C. B. (1962). Bull. Johns Hopk. Hosp., 110, 1.

Dawson, G. W. P. (1963). Personal communication.

Fisher, R. A. (1958). Nature (Lond.), 182, 596.

Friberg, L., Kaij, J., Dencker, S. J., and Jonsson, E. (1959). Brit. med. J., 1, 1090.

Hackett, W. E. R., and Dawson, G. W. P. (1958). Irish J. med. Sci., 6 ser., No. 398, p. 99.

_- and Dawson, C. J. (1956). Heredity, 10, 69.

McConneli, R. B., Clarke, C. A., and Downton, F. (1954). Brit. med. J., 2, 323.

Roberts, J. A. Fraser (1955). Proc. roy. Soc. Med., 48, 143.

Thomas, C. B., and Cohen, B. H. (1960). Bull. Johns Hopk. Hosp., 106, 205.

Todd, G. F., and Mason, J. I. (1959). Heredity, 13, 417.

Walther, W. W., Raeburn, C., and Case J. (1956). Lancet, 2, 970. 